Establishment of the Grasslands $\mathrm{Na}$ tional Park should ensure the long-term survival of prairie dogs. National park legislation will protect prairie dogs and their habitat from poisoning, shooting and severe land alterations. Prairie dogs will very likely become popular with park visitors and add to their enjoyment and understanding of the complex and fascinating prairie ecosystem.

1 FAGERSTONE, K.A. and D.E. BIGGINS 1986. Comparison of capture-recapture and visual count indices of prairie dog densities in black-footed ferret habitat. Great Bas. Nat. Memoirs No. 8. Pp. 94-99.

2 KING, J.A. 1955. Social behavior, social organization, and population dynamics in a Black-tailed Prairie Dog town in the Black Hills of South Dakota. Contributions from the Laboratory of Vertebrate Biology. Univ. of
Michigan, Ann Arbor. No. 67. 121 pp.

3 KOFORD, C.B. 1958. Prairie dogs, white faces, and Blue Grama. Wildl. Monogr. No. 3. $78 \mathrm{pp}$.

4 LAING, R. 1986. The feasibility of reintroducing the black-footed ferret to the Canadian prairie. Unpublished Masters Degree Project. The University of Calgary. Calgary, Alberta. $134 \mathrm{pp}$.

5 MILLSON, R. 1976. The black-footed ferret in the proposed Grasslands National Park. Unpublished Masters Degree Project. The University of Calgary. Calgary, Alberta. 107 pp.

6 O'MEILIA, M.E., F.L. KNOPF and J.C. LEWIS 1982. Some consequences of competition between prairie dogs and beef cattle. J. Range Mgmt. 35(5):580-584.

\title{
HOUSE SPARROW KILLED BY RED SQUIRREL
}

ROBERT W. NERO, Wildlife Branch, 1495 St. James Street, Winnipeg, Manitoba. R3H OW9

Although the Red Squirrel's carnivorous reputation was known to me, it was still a surprise to see one capture and run off with a House Sparrow. This happened at a bird feeder in our Winnipeg yard at 1:15 p.m., 25 July 1987. It was a bright, hot day. My wife, our son Birch, and I were relaxing in the shade $9 \mathrm{~m}$ from about 20 House Sparrows feeding close together on the lawn beneath the feeder which is fastened about $1 \mathrm{~m}$ high on a large Bur Oak. I had been casually watching the sparrows, particularly one with several white wing feathers. Suddenly, a squirrel ran up the tree with a sparrow hanging upside down in its mouth, followed by a flock of scolding sparrows. When we got to the tree the squirrel was perched on a limb about $4.6 \mathrm{~m}$ up, where it killed the sparrow. Alarmed by us, the squirrel left the sparrow on a limb and ran about $3 \mathrm{~m}$ higher. It returned shortly, retrieved the sparrow and carried it back up to the higher position. Then it left the bird and raced about the tree seeking to escape to adjacent trees. It was an adult, lactating female, presumably with young in some other yard.

The sparrow, a juvenile male weighing $25 \mathrm{gm}$, had deep lacerations on the left breast and right abdomen. It appeared to have no other injuries. Inexperienced and busily seeking food, it had apparently been taken by a surprise attack by the squirrel from around the base of the tree. This feeder regularly attracts both squirrels and several species of birds. The birds feed in the tray of the feeder as well as on the ground beneath. Often, they may be seen feeding on the ground at the same time that squirrels are in the feeder. Thus, there have been many opportunities to observe squirrel-bird interactions. Red 
Squirrels and House Sparrows have been using this feeding site for the past 15 years, summer and winter, but we have not previously seen a squirrel even attempt to catch a bird. Presumably the squirrel's drive was based on a need to feed young. However sunflower seeds were almost constantly available at the feeder. Moreover, over the past few years at least five families of Red Squirrels have fed here. Earlier this year one family came out of a cavity in a dead Trembling Aspen not

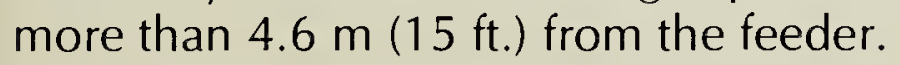
It may, in fact have been the same female that caught the sparrow. An hour and a half after the capture, what was apparently the same squirrel was in the feeder, eating sunflower seeds.

This squirrel's carnivorous habits were briefly noted by Pylypec "only in the spring and early summer," but Sealy successfully trapped them in winter near Battleford, Saskatchewan, using meat for bait. ${ }^{8} 9$ Nearly every account of the Red Squirrels' life history mentions its habit of preying on the contents of birds' nests and fledglings. ${ }^{1} 234567$ Even larger prey may be taken. Hamilton reported that they also killed young Eastern Cottontails and young Grey Squirrels. Banfield writes: "The red squirrel is far more carnivorous than the other tree squirrels and will eat practically anything it can catch that will not eat it. It has been known to eat deer mice, meadow voles, young cottontails, robins, bluebirds, orioles and ruffed grouse. One boldly entered a cavity occupied by a sawwhet owl and ate the cached mice." 1 A cautionary note is raised

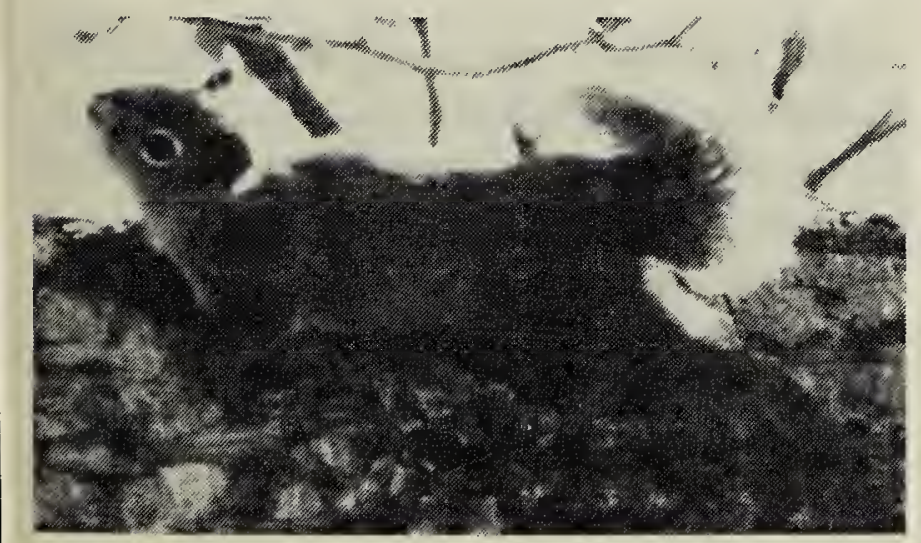

Red Squirrel

Frank Switzer by Cahalane: "The practice of nest robbing cannot be very general. Birds often have been known to rear their broods in the same trees with red squirrels, while the latter looked on and showed no gustatory interest. Some red squirrels have been terrorized by jays and robins, that never permitted the rodents to approach their nesting sites." 2 Klugh, an early student of the Red Squirrel summed up his views as follows: "It is probable that only certain red squirrels are bird-eaters, just as only certain tigers are man-eaters and such individuals should be destroyed as soon as evidence against them is obtained." 6 For the time being, at least, I plan to keep a close eye on the squirrels in our yard!

1 BANFIELD, A.W.F. 1974. The mammals of Canada. Univ. of Toronto Press, Toronto. 438 pp.

2 CAHALANE, V.H. 1954. Mammals of North America. MacMillan Co., N. Y. 682 pp.

3 CHAPMAN, J.A. and G.A. FELDHAMER, Eds. 1982. Wild mammals of North America. Johns Hopkins Univ. Press, Baltimore. 1147 pp.

4 HAMILTON, W.J. Jr. 1939. American mammals. McGraw-Hill Book Co., N.Y. 434 pp.

5 JACKSON, H.H.T. 1961. Mammals of Wisconsin. Univ. of Wisconsin Press, Madison. 504 pp.

6 KLUGH, A.B. 1927. Ecology of the Red Squirrel. J. Mammalogy 8:1-32.

7 PETERSON, R.L. 1966. The mammals of eastern Canada. Oxford Univ. Press, Toronto. $465 \mathrm{pp}$.

8 PYLYPEC, B. 1966. Rodents preying on birds. Blue Jay 24:201.

9 SEALY, S.G. 1966. Notes on the carnivorous tendencies of some sciurids. Blue Jay 24:37-38.

10 WOODS, S.E. Jr. 1980. The squirrels of Canada. Nat. Mus. of Nat. Sciences, Nat. Mus. of Canada, Ottawa. 199 pp. 